University for Business and Technology in Kosovo

UBT Knowledge Center

UBT International Conference

2016 UBT International Conference

Oct 28th, 9:00 AM - Oct 30th, 5:00 PM

\title{
The Role of knowledge management in the Information system
}

Sejdi Xhemaili

University for Business and Technology, sejdi.xhemaili@ubt-uni.net

Follow this and additional works at: https://knowledgecenter.ubt-uni.net/conference

Part of the Databases and Information Systems Commons, and the Information Security Commons

\section{Recommended Citation}

Xhemaili, Sejdi, "The Role of knowledge management in the Information system" (2016). UBT International Conference. 6.

https://knowledgecenter.ubt-uni.net/conference/2016/all-events/6

This Event is brought to you for free and open access by the Publication and Journals at UBT Knowledge Center. It has been accepted for inclusion in UBT International Conference by an authorized administrator of UBT Knowledge Center. For more information, please contact knowledge.center@ubt-uni.net. 
The Role of knowledge management in the Information system

\title{
The Role of knowledge management in the Information system
}

\author{
Sejdi Xhemaili \\ UBT - Higher Education Institution, Lagjja Kalabria, 10000 p.n., \\ Prishtine, Kosovo \\ sejdi.xhemaili@ubt-uni.net
}

\begin{abstract}
We are living in a world in which the knowledge is a precious commodity. The fast pace of the development of the companies both for trade and service require management of the acquired knowledge in the best possible way.

This paper would show the influence of the knowledge management in the information system - that is what is achieved when knowledge management itself is applied to the information system. The accumulated knowledge in terms of innovation, management of the staff and its training, competitiveness on the wide market and improvement of the level of the business processes and performance tend to change the companies themselves and here the focus will be put what would be achieved by implementing them in the information system.

There are points of view that discuss knowledge management and information systems as separate units or correspondent units, here they would be discussed as units that are somehow complementary to one another. The significance of sharing things between the two complementary systems is very important because they provide better access to the required information and in that way the human knowledge is improved in a faster way.

Also, it would be given a brief reflection of the level of implementation of the knowledge management in the information systems by the companies in the 21 st century and a background would be given on the first attempts of joining the two systems.

Nevertheless, positive sides such as: the level of management support, the influence in the organisational structure, planning, design, coordination, and evaluation, and the measure of the benefits and performance indicators, and the negative sides as well would be also discussed.
\end{abstract}

Keywords: knowledge management, Information system, organisational structure, planning, design, coordination, evaluation, benefits, performance indicators.

\section{Introduction}

The $21^{\text {st }}$ Century brought fast pace of business development and as such made the companies as well as administration do a lot of changes in order to respond in proper and efficient manner. The knowledge as such has become a valuable commodity making this century significant by providing vast resources of it. The way of implementing and using the knowledge itself in order to achieve higher effectiveness in the operational or service processes marks the proper management of the knowledge. The connection of the knowledge management and the information system is very important since the acquired 
Book of Proceedings

International Conference on Information Systems and Security

knowledge itself is not easy to sort out properly so this is where the information systems would provide assistance to help better and faster access to the end users.

\section{Knowledge management factors}

According to Kimiz Dalkir [ $\left.{ }^{4}\right]$ Knowledge Management itself has interwoven vast number of fields such as organisational, cognitive, technical writing, education and training and etc. The fields of innovation and management of the staff in such a way to provide competitiveness on the market and when providing services also have to be taken into consideration.

Several factors have to be taken seriously when applying Knowledge Management as according to Alan Frost $\left[{ }^{5}\right.$ ] if they are not implemented properly failure may occur:

Causal Failure Factors:

1. Lack of performance indicators and measurable benefits

2. Inadequate management support

3. Improper planning, design, coordination, and evaluation

4. Inadequate skill of knowledge managers and workers

5. Problems with organisational culture

6. Improper organisational structure

Each of these factors are crucial and interdependent of each other - which means if there is a lack of performance measurement the managers would be unable to provide proper managerial support which will have its effect on the planning, the staff and will inflict problems within the organization itself and its structure.

The end results may be described as specific problems such as:

Resultant Failure Factors:

1. Lack of widespread contribution

2. Lack of relevance, quality, and usability

3. Overemphasis on formal learning, systematisation, and determinant needs

4. Improper implementation of technology

5. Improper budgeting and excessive costs

6. Lack of responsibility and ownership

7. Loss of knowledge from staff defection and retirement

This is where the connection of knowledge management and information systems should be applied especially with the knowledge systems, documents and information and their proper distribution and allocation in order to be readily accessible to the end users.

\footnotetext{
${ }^{4}$ Kimiz Dalkir, Knowledge Management in Theory and Practice, Second Edition, McGill University's Graduate School of Information and Library Studies, March 2011 1-30

${ }^{5}$ Alan Frost M. Sc, A Synthesis of Knowledge Management Failure Factors, January 25, 2014 1-21
} 
The Role of knowledge management in the Information system

\section{Information systems}

Based on themselves the information systems are electronic devices supported by appropriate software and as per Wil M.P. van der Aalst and Christian Stahl [ ${ }^{6}$ ] it is "a software system to capture, transmit, store, retrieve, manipulate, or display information, thereby supporting people, organizations, or other software systems". Being as such it may provide strong support to the knowledge management since the acquired and accumulated knowledge originating from various sources business, technical and administrative as well could not be easily organized.

There are three types of information systems types of information systems such as: personal information systems, Enterprise (or organizational) information systems and public information systems. Each of them is applied and serves for its basic usage as per designated group it belongs.

Their capability with the software applied as per specific type of information system makes them a precious asset to the fast transfer and access to the required information.

\section{Knowledge management and Information Systems}

The fast pace of development and the need of better access to knowledge information has made the implementation of computerized systems a necessity within the knowledge management. Although these two segments are discussed as separate items - they should not be separated. What is more they need to be viewed as a whole where Information Systems provide a support to the Management of the knowledge.

This suggests probably a creation of one more type of Information systems which will support the knowledge management and let's say to name it Knowledge Management Information System. It may be derived from the existing Enterprise (or organizational) information systems since they combine various subsystems. However, this system should be focused on the acquired and accumulated knowledge from the various areas business, trades, economy and administration as well.

The implementation of appropriate and specific software will enable the Information System to:

- Sort

- Index

- Classify and

- Order

The information it gains from the knowledge and later it may file them under specific area it denotes within the documents themselves.

The knowledge management information system may be presented as in figure 1

${ }^{6}$ Wil M.P. van der Aalst and Christian Stahl, Modeling Business Processes May 2011, 1-40 
Book of Proceedings

International Conference on Information Systems and Security

Acquired and accumulated Knowledge

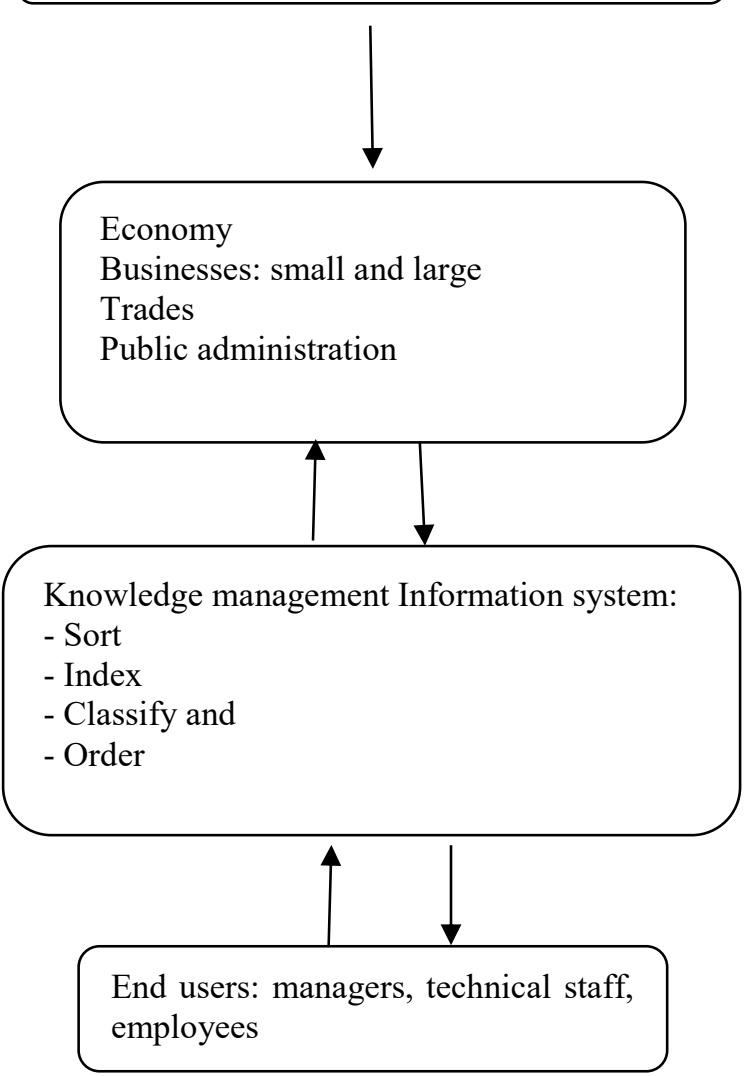

Figure 1 Knowledge management Information system

The acquired and accumulated knowledge flows into one segment that stores everything for which has made an input into the information system. The next stage is where the computer technology supported by an appropriate software comes into the scene and works on the Sorting, Indexing, Classifying and Ordering of the information.

The two way arrows show that this process is ongoing. That it doesn't stop since there is always something new to be added since every single day may create additional information or experience which should be shared and in that way the knowledge itself gets richer. Regardless of the nature of the experience whether positive or negative it gets acknowledged and if positive applied as needed or if negative avoided in case it has been seen in a certain situation.

The end users are those who give the final assessment of the effectiveness of the system. The two way arrows show that their input is also very important. Their views may also improve the knowledge database. 
The Role of knowledge management in the Information system

\section{Conclusion}

The vast field of knowledge management becomes harder to be manipulated with on one hand on the other hand the fast pace of the processes in the $21^{\text {st }}$ century require faster access to the vital information in order to improve the organizations' output and performance. The managers are forced to be effective in their planning and management of an organization in order to achieve higher effectiveness.

However, the process of implementation of knowledge management may face itself with various Casual and Resultant failure factors. These have to be avoided in order to achieve to goals that are set. This is where proper knowledge management comes into its importance. What is more the volume of information being enormous itself is very hard for an individual to review and to choose in timely manner which is the best option for the subject matter. Having said this, Information systems are those which would made that happen.

It should also be noted that the input of information is a demanding process which requires precise manner of input of all the acquired information. The precisely entered information will enable proper Sorting, Indexing, Classifying and Ordering of the information which on the other hand will support faster access to the vital and proper segments of needed information.

Knowledge Management Information System are something which should be looked forward to in this century of high technology and fast pace of life and work.

\section{References}

1. Dalkir Kimiz, Knowledge Management in Theory and Practice, Second Edition, McGill University's Graduate School of Information and Library Studies, March 2011 1-30

2. Frost Alan M. Sc, A Synthesis of Knowledge Management Failure Factors, January 25, 2014 121

3. Wil M.P. van der Aalst and Christian Stahl, Modeling Business Processes May 2011, 1-40 